\title{
Kontribusi zakat, infak, sadaqab dan wakaf terhadap civil society (studi kasus di Yayasan Solopeduli Surakarta)
}

\author{
Muh. Zumar Aminuddin \\ Fakultas Syariah dan Ekonomi Islam \\ Institut Agama Islam Negeri Surakarta \\ Jl. Pandawa Pucangan Kartosuro Sukoharjo Jateng \\ Email:Zumar1974@gmail.com
}

This research aims to describe the contributions of zakat, infak, șadaqah and wakaf (Islamic philanthropy) toward the civil society movements in Indonesia and the problems surrounding it. This study raised the case of Yayasan Solopeduli Surakarta, an Islamic philanthropy management agencies. This research uses the socilogical approache of law. The primary data sources are administrators and managers, and agency activities organized by the Yayasan Solopeduli Surakarta. Secondary data are relevant papers, brochures and dictionaries. Data were collected by interview and observation and documentation. Data analysis was performed with a fixed ratio (constant comparative method) which includes data reduction, categorization and synthesization, as well as the formulation of an answer. In the analysis process, the data are associated with theories of civil society. The findings of this research show that zakat, infak, s \}adaqah and wakaf managed by Yayasan Solopeduli Surakarta contributes to the formation of the pillar of civil society and the enforcement of civil society values. Firsly the charity value as showed by existence of the agency that always builds the care spirit of the haves for the poor, as well as by most its programs that offer free service concept, in the field of education, health, and other public service. Secondly, the independence value, especially from the aid of the government. The impact is, that the agency moves freely by itself paradigm. Thirdly juctice value as showed by the most programs that support the poor society. However, actually the agency is far from, but doesn't recognize the civil society discourse as seen by the west. That is why, it doesn't go along with the contemporery issue of civil society, such as democracy and gender equality. The interpretation of mustahiq surrounds the classic one.

Penelitian ini bertujuan untuk menjelaskan bagaimana filantropi Islam memiliki sumbangan terhadap gerakan civil society di Indonesia dan problem yang melingkupinya. Penelitian ini mengangkat kasus Yayasan Solopeduli Surakarta, sebuah lembaga pengelola filantropi Islam. penelitian ini menggunakan pendekatan sosiologi hukum. Sumber data primernya adalah pengurus dan pengelola kegiatan serta 
ljtihad, Jurnal Wacana Hukum Islam dan Kemanusiaan, Volume 13, No. 2, Desember 2013: 199-217

lembaga yang diselenggarakan oleh Yayasan Solopeduli. Sedangkan data sekunder adalah karya tulis yang relevan, brosur, kamus. Data dikumpulkan dengan teknik wawancara dan observasi serta dokumentasi. Analisis data dilakukan dengan perbandingan tetap (constant comparative method) yang meliputi reduksi data, kategorisasi dan sintesisasi, serta perumusan jawaban. Dalam proses analisis, data dikaitkan dengan teori-teori civil society. Hasil penelitian menunjukkan bahwa zakat, infak sedekah dan wakaf telah memberikan kontribusi terhadap gerakan dan penegakan pilar-pilar civil society. Pertama, penegakan nilai kedermawanan yang ditunjukkan oleh eksistensi lembaga ini yang selalu berusaha membangun semangat kepedulian dari orang-orang mampu kepada mereka yang tidak mampu. Juga ditunjukkan oleh hampir seluruh programnya yang menawarkan konsep gratis, terutama dalam bidang pendidikan, kesehatan dan layanan masyarakat ainnya. Kedua, nilai kemandirian, terutama kemandirian dari ketergantungan terhadap bantuan pemerintah. Kemandirian ini memungkinkan lembaga ini bergerak sesuai dengan paradigmanya sendiri, tanpa intervensi pemerintah. Ketiga, nilai keadilan. Hal ini ditunjukkan melalui program-programnya yang keseluruhannya ditujukan untuk membantu masyarakat miskin. Namun sebenarnya lembaga ini jauh, bahkan tidak mengenal wacana civil society itu sendiri, sehingga tidak bisa mengikuti perkembangan kontemporer, seperti isu demorasi dan kesetaraan gender. Tafsir tentang mustahiq juga masih mengacu pada penafsiran klasik.

Keywords: ZISWAF, Contribution, Fundraising, Distribution, Civil Society, a free service.

\section{Pendahuluan}

Zakat, infak, șadaqah, infak dan wakaf (selanjutnya disingkat Ziswaf) yang bisa disebut sebagai filantropi Islam (Prihatna, 2005:6) telah memainkan peran yang cukup besar, terutama bagi perkembangan Islam dan peradaban manusia secara umum. Sejarawan M. Arnaut menyatakan bahwa Islam sepanjang sejarahnya dan di mana saja sulit dibicarakan tanpa wakaf (Arnaut, 2000:7).

Pada masa Nabi dan para khalifah sesudahnya, Ziswaf, terutama zakat merupakan sumber keuangan "negara” ketika itu (Tim Penulis UII,2008:489). Tanpa Ziswaf "negara” akan mengalami kesulitan keuangan. Dilihat dari perspektif ini tindakan Abu Bakar memerangi para pembangkang zakat merupakan upaya untuk menyelamatkan negara. Tentu saja pandangan demikian tidak menafikan bahwa tindakan khalifah pertama itu merupakan upaya untuk menjaga integritas ajaran Islam itu sendiri. Namun bahwa zakat sangat dibutuhkan oleh negara tidak bisa dipungkiri.

Di negara modern, terlebih yang tidak berdasarkan Islam, termasuk Indonesia, peran Ziswaf tidak lagi menjadi sumber keuangan negara, melainkan sumber pendanaan gerakan 
masyarakat sipil. Gerakan itu terutama dalam upaya untuk mengembangkan melalui masjid, lembaga pendidikan, kesehatan dan institusi keagamaan lainnya. Institusi itu lahir dari gerakan masyarakat baik perorangan maupun organisasi di luar negara.

Filantropi Islam di atas sering hanya dilihat sebagai gerakan karikatif yang bermotif agama. Biasanya berkisar pada permasalahan fiqh yang melihat segi sah dan tidaknya Ziswaf, atau persoalan tasawuf yang menekankan keikhlasan pelakunya. Sementara dampak yang yang ditimbulkan oleh filantropi itu sendiri tidak begitu mendapat perhatian. Di sinilah pentingnya mengkaitkan gerakan filantropi ini dengan gagasan civil society.

Dalam dua dasawarsa terakhir ini banyak lembaga non-pemerintah baru pengelola dana filantropi Islam lahir di Indonesia, baik yang bersekala nasional maupun lokal. Kehadiran lembaga-lembaga itu melengkapi lembaga-lembaga pengelola filantropi yang telah ada terlebih dahulu, terutama yang berbentuk ormas Islam, seperti Muhammadiyah dan NU.

Kehadiran lembaga-lembaga filantropi baru tersebut mengindikasikan adanya potensi filantropi yang belum tergali, sehingga kehadirannya masih mendapat tempat. Beberapa penelitian memang menunjukkan besarnya potensi dana itu. Penelitian yang dilakukan oleh Baznas menyebutkan bahwa Potensi Zakat Nasional tahun 2011 adalah Rp 217 trilliun (http:/ Limz.or.id/new/news/896/potensi-zakat-nasional-217-t). Potensi itu cenderung meningkat setiap tahun, seiring dengan peningkatan perekonomian masyarakat. Jika potensi zakat saja sedemikian besar, berarti keseluruhan dana filantropi Islam, baik infaq, sadaqah maupun wakaf jauh lebih besar lagi.

Besarnya potensi dana filantropi Islam merupakan modal besar bagi tumbuh berkembangnya civil society dengan lembaga-lembaga pengelolanya sebagai aktor. Jika dibandingkan dengan negara jiran Malaysia yang banyak mendapat dukungan dana dari pemerintah, lembaga-lembaga di Indonesia, dengan dukungan dana filantropi, bisa membiayai diri sendiri, sehingga relatif aman dari intervensi negara (Azra, 2006:xiv). Dalam kontek demikian Yayasan Solopeduli Surakarta hadir.

Yayasan Solopeduli memiliki karakter yang relatif unik dibandingkan pengelola Ziswaf yang lainnya terutama ormas Islam. Keunikan itu adalah konsepnya yang serba gratis dalam memberikan pelayanan kepada masyarakat, terutama masyarakat lemah. Negara saja tidak memiliki konsep demikian, setidaknya jika dilihat dari fakta bahwa belum semua layanan negara 
ljtihad, Jurnal Wacana Hukum Islam dan Kemanusiaan, Volume 13, No. 2, Desember 2013: 199-217

diberikan secara gratis. Dilihat dari sisi ini Yayasan Solopeduli telah melakukan tugas negara sebagaimana diamanatkan dalam Pembukaan UUD 1945. Maka penelitian mengenai Ziswaf melalui Yayasan Solopeduli berkontribusi terhadap gerakan civil society menarik untuk dilakukan.

Berdasarkan uraian pada pendahuluan di atas rumusan masalah penelitian ini adalah nilai-nilai civil society apa yang telah dipraktikkan di dalam pengelolaan Ziswaf di Yayasan Solopeduli serta hambatan apa yang dihadapi oleh Yayasan ini dalam mempraktikkan nilainilai civil society.

Sejalan dengan rumusan masalah, tujuan penelitian ini adalah untuk mendeskripsikan nilai-nilai civil society yang telah dipraktikkan dalam pengelolaan ziswaf di Yayasan Solopeduli Surakarta dan hambatan-hambatan apa yang dihadapi dalam mempraktikkan nilai-nilai civil society. Kontribusi penelitian ini setidaknya adalah pembacaan filantropi Islam dari kaca mata civil society, sehingga semakin memperkuat kompatibilitas keduanya sekaligus mencermati hambatan-hambatannya. Kontribusi yang lebih dalam lagi adalah memperkaya kerangka gerakan bagi filantropi Islam, yaitu dengan kerangka civil society, sehingga gerakan filantropi Islam lebih bermakna bagi kehidupan masyarakat.

\section{Metode penelitian}

Penelitian ini berangkat dari institusi hukum Islam, yaitu zakat, infak, sedekah dan wakaf, yang ditekankan pada dimensi sosialnya. Dimensi sosial yang dimaksud adalah pengaruhnya terhadap civil society dalam kehidupan masyarakat. Oleh sebab itu penelitian ini merupakan socio-legal research. Ziswaf sebagai norma agama, dilihat sebagai fenomena sosial yang berpengaruh terhadap tatanan sosial. Selanjutnya tatanan sosial yang lahir dari gerakan filantropi Islam itu dilihat melalui kaca mata civil society.

Fokus penelitiannya adalah lembaga keagamaan, yaitu Yayasan Solopeuli. Menurut Keith A. Robert lembaga keagamaan dalam penelitian agama dengan pendekatan sosiologis adalah pranata sosial yang menjadi infrastruktur tegaknya agama dalam masyarakat, yang meliputi organisasi keagamaan, pemimpin agama, jamaah, upacara keagamaan, sarana peribadatan dan proses sosialisasi doktrin-doktrin keagamaan (Prayogo dan Tobroni, 2003:61).

Sumber data primer adalah para pengelola Yayasan Solopeduli Surakarta. Sedangkan sumber daya sekunder adalah data-data tertulis yang memberi informasi yang relevan, 
misalnya brosur dan iklan Yayasan Solopeduli, majalah Hadila (majalah keluarga yang diteritkan Yayasan ini) serta karya-karya yang relevan. Sedangkan sumber data tersier adalah kamus, baik Arab maupun Inggris. Data yang digali adalah profile Yayasan dan aktifitas pengelolaan ziswaf yang dilakukannya, serta gagasan-gagasan yang menjadi latar belakangnya.

Data digali melalui teknik wawancara, survey dan dokumentasi. Wawancara dilakukan terhadap sumber data primer, yaitu pengelola Yayasan Solopeduli. Survey dilakukan terhadap aktifitas Yayasan, sedangkan dokumentasi dilakukan terhadap sumber data sekunder dan tersier, yaitu dokumen dan karya-karya relevan.

Data yang telah diperoleh dianalisis secara deskriptif kualitatif dengan metode perbandingan tetap (constant comparative method) yang meliputi reduksi data, kategorisasi dan sintesisasi, serta perumusan jawaban (Moleong, 2009:288-289). Reduksi data adalah mengidentifikasikan satuan (bagian terkecil) data yang berkaitan dengan pokok permasalahan dan sekaligus membuang data yang tidak relevan.

Setelah direduksi, data dikategorisasikan, yaitu dipilah ke dalam bagian yang memiliki kesamaan. Berikutnya adalah sintesisasi, yaitu mengaitkan antara satu kategori data dengan kategori data yang lain sehingga tersusun jalinan yang dapat memberi penjelasan atas permasalahan penelitian. Pada langkah ini teori civil society digunakan sebagai perekat data, sehingga deskripsi yang tersusun tidak murni apa adanya melainkan dengan perspektif civil society. Langkah terakhir adalah penyusunan jawaban, yaitu pernyataan proposisional yang terkait dengan data dan merupakan jawaban atas permasalahan penelitian.

\section{Ziswaf dan civil society}

\section{Ziswaf}

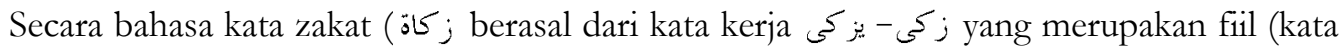
kerja intransitif) yang berarti suci, tumbuh, berkah dan terpuji (Qardhawi, 2007:34). Secara istilah zakat adalah sejumlah harta tertentu yang diwajibkan Allah diserahkan kepada orangorang yang berhak (Qardhawi, 2007:34). Sedangkan menurut UU Nomor 23 Tahun 2011 tentang Pengelolaan Zakat, Zakat adalah harta yang wajib disisihkan oleh seorang muslim atau badan yang dimiliki oleh orang muslim sesuai dengan ketentuan agama untuk diberikan kepada yang berhak menerimanya. 
ljtihad, Jurnal Wacana Hukum Islam dan Kemanusiaan, Volume 13, No. 2, Desember 2013: 199-217

Sedangkan sadaqah (صدقة) berasal dari kata صدق - يصدق yang berarti benar. Dalam hal ini benar pengakuan iman seseorang. Kata ini sering dipakai dalam ayat al-Qur'an untuk maksud zakat. Juga dipakai untuk maksud mahar. Cakupan kata ini juga meliputi hal-hal yang bersifat non-materiil, seperti mengucapkan kata-kata yang baik, senyum, hubungan suami istri dan melakukan kegiatan amar ma'fuf nahi munkar (Hafiduddin, 1998:15). Dengan demikian cakupan sedkah lebih luas dari pada zakat.

Sementara kata infaq (انفاق berasal dari kata انفق - انفق berari menjadi miskin, habis perbekalan dan membelanjakan (Munawir, 2007 : 1548, Ali,tt : 262). Kata ini mengacu secara lebih spesifik kepada harta (materi). Maka dalam kaitannya dengan harta, kata infaq lebih tepat dibanding kata shadaqah. Cakupan kata $s\} a d a q a h$ juga lebih luas dari infaq. Maka kata infaq cocok untuk disandingkan dengan kata zakat, dimana zakat bersifat wajib sedangkan infaq bersifat sunah. Namun demikian menurut Didin Hafiduddin infak dan s jadaqah memiliki makna yang sama, termasuk hukum dan ketentuan-ketentuannya (Hafiduddin, 1998:15).

Sedangkan Wakaf Secara bahasa berarti منع atau mencegah dan حبس atau menahan (Munawir, 1997:1682). Wakaf bersinonim dengan kata at-tabbis dan at-tasbïl (Zuhailiy, tt:8599). Kata lain yang juga dipakai untuk maksud wakaf adalah șodaqoh (Syalabi, 1957: 19). Dilihat dari ilmu shorof kata al-Waqf (الوقف) merupakan bentuk masdar (gerund) dari kata waqafa (وقف). Ibn Mandzur menyatakan bahwa kata abbasahu berarti amsakahu (menahannya). Kalimat habbasa al-faros fí sabilillāh (حبس الفرس في سبيل الله berarti mewakafkan kuda kepada tentara untuk ditunggangi ketika perang fi sabīl Alläh. Sedangkan kalimat waqf al-ard 'alà al-masākin (وقف الارض على المساكين) berarti mewakafkan tanah kepada orang-orang miskin (Ibn Mandzur, $1301 \mathrm{H} /$ jilid 11:276).

Menurut UU No 41 tahun 2004 tentang Wakaf Pasal I ayat (1), wakaf adalah perbuatan hukum wakif untuk memisahkan dan/atau menyerahkan sebagian harta benda miliknya untuk dimanfaatkan selamanya atau untuk jangka waktu tertentu sesuai dengan kepentingannya guna keperluan ibadah dan/atau kesejahteraan umum menurut syari'ah. 


\section{Civil society}

Secara bahasa civil society berarti masyarakat sipil. Dalam Kamus besar Bahasa Indonesia sipil berarti penduduk atau rakyat yang bukan militer (Pusat Bahasa, 2008:1467). Secara istilah, civil society telah mengalami pergeseran pengertian dari waktu ke waktu. Dalam sejarahnya ia lahir di Barat bersamaan dengan proses modernisasi, terutama pada saat terjadi transformasi dari masyarakat feodal menjadi masyarakat Barat modern ( Ubaidillah, 2000:137).

Modernisasi di Barat, yakni di Eropa itu terjadi ketika kaum borjuis bangkit melawan tirani sistem monarkhi yang absolut, kekuasaan gereja yang begitu besar dan keserakahan kaum feodal. Kebangkitan kaum borjuis ini mendapat dukungan dari pemikiran para filosuf seperti Hegel, Ferguson dan De Tocquiville yang memimpikan berkumpulnya invididuindividu sipil untuk melindungi dan meningkatkan terpenuhinya kepentingan bersama di hadapan otoritas negara (Harmsen, 2007:16)

Menurut Hikam (1999:116-118) pada sekitar pertengahan abad XVIII M civil society dianggap sama dengan state (negara), yaitu satu kelompok yang mendominasi kelompok lain. Pandangan ini berubah pada paruh akhir abad delapan belas. Civil society tidak lagi dianggap sama dengan negara, melainkan dua entitas yang berbeda. Namun ada beberapa pandangan yang berbeda. Hegel berpandangan bahwa civil society adalah lembaga sosial yang berada antara keluarga dan negara yang dipergunakan oleh warga untuk mencapai pemuasan kepentingan individu dan kelompok. Sedangkan Marx yang berambisi menghapuskan kelas masyarakat melihat civil society sebagai kaum borjuis yang harus dilenyapkan. Menurut Hikam konsepsi terakhir civil society dikemukakan oleh Alexis de Tocquiville yang memposisikan civil society sebagai kekuatan penyeimbang negara yang memiliki kekuatan untuk mengekang atau mengontrol kekuatan intervensionis negara.

Sedangkan menurut Azra (2000:viii) studi terakhir tentang masyarakat sipil membantah pandangan Alexis de Tocquiville di atas. Menurutnya civil society yang disebutnya masyarakat madani memang merupakan entitas yang berbeda dengan negara. Namun keduanya tidak dalam posisi berhadap-hadapan, sebaliknya terjalin hubungan yang lebih kooperatif.

Menurut Hikam ciri utama civil society adalah keswasembadaan dan kesukarelaan sehingga mampu melakukan kiprahnya sendiri secara swasembada. Orientasi kiprah civil society adalah kewarganegaraan yang berintikan pada penghormatan hak-hak asasi manusia (Hikam, 
ljtihad, Jurnal Wacana Hukum Islam dan Kemanusiaan, Volume 13, No. 2, Desember 2013: 199-217

1999:85). Pilar civil society antara lain lembaga swadaya masyarakat, pers, supremasi hukum, perguruan tinggi dan partai politik (Ubaidillah, 2000:150).

Secara lebih rinci Ubaidillah menyebutkan enam karakteristik civil society (Ubaidillah, 2000:147-149) sebagai berikut:

a. Free Public Sphere, yaitu wilayah dimana masyarakat sebagai warga negara memiliki akses penuh terhadap setiap kegiatan publik, melakukan kegiatan secara merdeka, berserikat, berkumpul serta menyampaikan informasi kepada publik.

b. Demokratis, yaitu bahwa masyarakat dapat berlaku santun dalam pola hubungan interaksi dengan masyarakat sekitarnya dengan tidak mempertimbangkan suku, ras, dan agama.

c. Toleran, yaitu kesiapan untuk menerima pandangan yang berbeda.

d. Pluralime, yaitu kesiapan untuk menerima keragaman dalam berbagai bentuknya.

e. Keadilan sosial, yaitu kondisi dimana warga masyarakat dapat merasakan kemajuan ekonomi secara bersama.

\section{Kontribusi ziswaf terhadap civil society}

\section{Yayasan solopeduli merupakan pilar civil society}

Yayasan solopeduli adalah wujud paling nyata dari kontribusi ziswaf terhadap civil society. Yayasan ini merupakan wujud free public sphere tempat masyarakat, khususnya para pendirinya, berserikat untuk mengekpresikan gagasannya. Tanpa lembaga sebagai wadah, masyarakat sulit mengorganisir diri dan melakukan sesuatu secara bersama. Lembaga swadaya masyarakat di luar negara merupakan pilar utama civil society (Kamil, 2013: 131).

Jika para pemikir seperti Hegel, Ferguson dan De Tocquiville, yang pemikirannya mengiringi gerakan civil society di Eropa memimpikan berkumpulnya individu-individu untuk membela kepentingan bersama dalam posisi menghadapi hegemoni negara, Yayasan Solopeduli lahir dari kondisi sosial ekonomi yang melanda Indonesia tahun 1998. Ketika itu terjadi krisis ekonomi yang mengakibatkan melonjaknya angka kemiskinan. Jadi Yayasan ini lahir bukan untuk menghadapi hegemoni negara, namun justru untuk ikut mengatasi persoalan yang dihadapi oleh negara, yaitu kemiskinan.

Sosok penggagas dan pendiri Yayasan ini adalah Danie H. Soe’oed dan Mulyanto Utomo dari koran Solopos serta Eri Sudewo dari Dompet Dhuafa Republika Jakarta. Nama terakhir 
ini sudah tidak asing di dunia filantropi Islam di tanah air. Ketiga tokoh itu berasal dari dunia pers, yang juga merupakan bagian dari civil society. Media massa, termasuk pers memiliki kekuatan untuk menjaga dan memberikan pendidikan civil society kepada masyarakat (Moore, 2007: 10). Dilihat dari latar belakang ketiga tokoh pendirinya, nuansa civil society Yayasan ini sangat kental.

Motif sosial ekonomi, dan bukan motif keagamaan yang melatarbelakangi berdirinya Yayasan ini semakin mendekatkannya dengan semangat civil society yang tidak primordial (Harmsen, 2007:34). Meskipun motif keagamaan tidak selalu identik dengan primordialisme, karena agama Islam memiliki nilai-nilai universal yang melampaui sekat sektarian, namun potensi ke arah sana cukup besar. Dengan motif sosial ekonomi, setidaknya semangat awal berdirinya Yayasan ini terhindar dari potensi itu.

Yayasan ini telah memanfaatkan Ziswaf sebagai sumber utama gerakannya sejak awal. Dengan demikian institusi Ziswaf yang menginspirasi. Kaitan antara Yayasan ini dengan institusi Ziswaf bisa dilacak sejak awal berdirinya dengan melihat salah satu sosok pendirinya, yaitu Eri Sudewa yang juga merupakan sosok penting berdirinya Dompet Dhuafa Jakarta. Lembaga ini menjadi ikon pengelolaan Ziswaf di tingkat nasional. Oleh sebab itu di depan telah dinyatakan bahwa Yayasan ini sendiri merupakan wujud kontribusi Ziswaf terhadap civilsociety.

\section{Kedermawanan dan Kesukarelaan}

Yayasan Solopeduli menggerakkan kedermawanan melalui institusi Islam, yaitu Ziswaf. Dana yang disumbangkan memang tidak hanya Ziswaf. Yayasan ini juga menerima sumbangan sosial lain, namun Ziswaf tetap merupakan yang terbesar. Pilihan ini cukup strategis mengingat mayoritas penduduk Indonesia adalah umat Islam. Pada diri ziswaf sendiri sebenarnya terdapat unsur kedermawanan yang sangat dominan, sehingga ia disebut filantropi Islam. Namun sebagai sebuah ajaran normatif yang abstrak, ziswaf tidak bisa menggerakkan diri sendiri menjadi kongrit. Harus ada sarana yang dalam sosiologi hukum disebut unsur penegak hukum, yaitu wadah yang memainkan peran untuk menegakkan aturan (Soekanto,2002:13). Dalam hal ini Yayasan Solopeduli berposisi pemegang peran itu untuk menegakkan ajaran Ziswaf. 
ljtihad, Jurnal Wacana Hukum Islam dan Kemanusiaan, Volume 13, No. 2, Desember 2013: 199-217

Yayasan Solopeduli menempuh berbagai cara untuk mensosialisasikan, menggerakkan dan mempromosikan Ziswaf kepada masyarakat. Ada dua cara pokok, yaitu relawan dan media massa.

\section{a. Relawan}

Relawan adalah orang-orang yang secara suka rela bersedia membantu Yayasan Solopeduli menggalang Ziswaf dari masyarakat. Relawan berasal dari berbagai kalangan. Ada dari kalangan mahasiswa, pegawai negari karyawan swasta dan masyarakat umum. Mereka tidak dibatasi oleh latar belakang politik dan organisasi keagamaan. Para relawan tidak diberi honor, bahkan mereka juga merupakan donatur. Mereka mendapatkan fasilitas yang bersifat pembinaan. Misalnya pelatihan parenting, temu duta peduli, jaket dan akses informasi program-program Yayasan.

Relawan Yayasan Solopeduli disebut Duta Peduli. Pada mulanya mereka adalah donatur yang dianggap berprestasi, yaitu jika berhasil mengajak minimal 10 orang untuk menjadi donatur (wawancara dengan Septo Budiawan, 20 Juni 2013). Untuk mendapat donatur baru, donatur lama dapat mengajak teman kerja, saudara, tetangga dan orangorang dekat lainnya. Namun yang jelas Yayasan tidak mengharuskan, melainkan atas dasar kerelaan masing-masing relawan dan donatur. Dengan sistem yang relatif unik ini jumlah relawan dan donatur yang dibinanya tumbuh semakin banyak seperti sel yang membelah.

b. Memanfaatkan Media Cetak

Yayasan Solopeduli memang dekat dengan media, terutama media cetak. Para pendirinya adalah tokoh-tokoh pers sebagaimana dijelaskan di depan. Kantor pusatnya juga satu komplek dengan kantor koran Harian Solopos. Maka tidak mengherankan jika Yayasan ini cukup gencar memanfaatkan media cetak untuk menginformasikan dan mempromosikan program-programnya.

Yayasan Solopeduli menerbitkan dua majalah, yaitu majalah Hadila dan Smarteens. Hadila diperuntukkan bagi donatur dewasa yang menyumbang minimal Rp. 10.000,-, sedangkan Smarteen untuk remaja yang menyumbang minimal Rp. 5000,-. Kehadiran majalah ini juga merupakan salah satu upaya untuk menjaga konsistensi para donatur, Selain sebagai sarana melakukan komunikasi, kedua majalah ini merupakan semacam 
“pengikat” bagi para donatur. Majalah Hadila memuat berbagai informasi dalam berbagai bidang, antara lain bidang agama, ekonomi, budaya dan sebagainya layaknya majalah umum. Hal yang tentu saja tidak pernah tertinggal adalah promosi program Yayasan.

Selain majalah terbitan sendiri, promosi ZISWAf juga dilakukan melalui majalah lain, yaitu majalah Ummi, sebuah majalah keluarga bertaraf nasional, yaitu Majalah UMMI. Misalnya N0. 12/XXI/April 2010/1431 H dan di UMMI No.2 /XIV/Februari 2012/ 1433 H. Disamping majalah, juga mencetak Company Profile yang berisi informasi singkat namun lengkap, yang dibagikan kepada para tamu serta dikirim ke lembagalembaga.

c. Promosi melalui internet

Yayasan Solopeduli juga memanfaatkan kemajuan teknologi, yaitu penggunaan media internet. Web site yang dimiliki oleh Yayasan Solopeduli adalah www.solopeduli.com. Web ini memuat berbagai informasi mengenai Yayasan, baik profile maupun program dan berita kegiatan yang dilakukan.

\section{Kemandirian}

Dengan dana Ziswaf, Yayasan Solopeduli dapat menjalankan program-programnya. Yayasan ini sudah dapat dikatakan mandiri, dalam pengertian tidak tergantung dari sumbangan pemerintah. Hal ini berarti bahwa ia telah memiliki dasar kemandirian sebuah gerakan civil society. Dibandingkan dengan lembaga-lembaga yang tidak mendapat bantuan pemerintah tetapi mendapat kucuran dana dari negara asing, Yayasan ini relatif lebih mandiri. Lembaga yang didanai asing tidak menutup kemungkinan justru cenderung mendukung agenda sponsor dari pada kepentingan domestik (Priyatna,2005: 17).

Yayasan Solopeduli menghimpun dana dari masyarakat yang nominalnya relatif kecil. Hal ini justru berdampak positif terhadap kemandirian lembaga. Yayasan tidak tergantung pada donatur tertentu. Secara logika maupun berdasarkan pengalaman, tidak mungkin terjadi pengunduran diri donatur secara masal. Kalaupun ada satu atau beberapa yang mengundurkan diri, program yayasan tidak begitu terpengaruh (Wawancara dengan Supomo, 14 Mei 2012). Kecenderungan yang terjadi justru semakin bertambah. Dengan demikian Yayasan ini tidak dikendalikan oleh pihak tertentu. 
ljtihad, Jurnal Wacana Hukum Islam dan Kemanusiaan, Volume 13, No. 2, Desember 2013: 199-217

Di samping mengandalkan dana Ziswaf, Yayasan juga berupaya menyelenggarakan program kegiatan yang berorientasi profit, diantaranya BMT yang diberi nama Mitra Niaga. Pendirian BMT Mitra Niaga sebenarnya merupakan tindak lanjut dari cukup banyaknya donatur tetap yang mencapai puluhan ribu. Mereka merupakan mitra untuk mengembangkan berbagai kepentingan, tidak hanya yang berkaitan dengan Ziswaf, namun juga bisnis. (Wawancara dengan Supomo, 14 Mei 2013).

Lembaga ini juga melakukan bisnis hewan kurban dan aqiqah sekaligus mendistribusikannya kepada yang berhak. Dengan bisnis semacam ini lembaga telah melakukan dua hal sekaligus. Pertama, bisnis yang berorientasi profit. Keuntungannya kembali pada lembaga untuk mendukung program-programnya. Kedua, gerakan berderma, karena kuban dan aqiqah sendiri merupakan tindakan berderma. Terlebih lagi pihak yang mendistribusikan adalah Yayasan Solopeduli sendiri, sehingga semakin mendukung program-programnya. Pihak yang berkurban atau beraqiqah mendapat laporan pelaksanaannya.

Bisnis hewan kurban dan aqiqah di atas disebut oleh Zaim Saidi sebagai kewiraswastaan sosial. Hal yang sama juga telah dilakukan oleh Dompet Dhuafa (Abidin,2005). Model ini melampaui Ziswaf, namun memiliki substansi yang sama, yaitu menggerakkan kedermawanan melalui ajaran agama. Model ini dapat mengurangi ketergantungan pada dana Ziswaf. Namun sampai sekarang dana Ziswaf masih merupakan andalan.

Meskipun independen dari negara, namun Yayasan ini tidak anti negara. Yayasan ini didirikan bukan merupakan oposisi terhadap negara, melainkan wujud keprihatinan terhadap terpuruknya kondisi sosial ekonomi masyarakat akibat krisis tahun 1998 dan sama sekali jauh dari wacana politis dan kritis terhadap pemerintah. Kegiatan Yayasan ini cenderung menjadi mitra pemerintah.

\section{Keadilan}

Civil society dipandang sebagai salah satu komponen penting untuk mewujudkan keadilan sosial (Priyatna, 2005:12). Tidak hanya itu, bahkan keadilan sosial merupakan karakter civil society itu sendiri. Maka semakin besar kontribusi terhadap peningkatan keadilan sosial, semakin kuat karakter civil societynya. Di Yayasan Solopeduli karakter civil society itu justru bersumber dari dana yang dikelolanya, yaitu Ziswaf itu sendiri. 
Ziswaf tidak hanya memiliki semangat kedermawanan, namun juga keadilan sosial. Dilihat dari sudut pandang donatur, Ziswaf mengajarkan kedermawanan. Namun jika dilihat dari sisi mustahiq, ia mengajarkan keadilan. Lebih jauh lagi ajaran keadilan sosial itu dapat dilacak dari ajaran Islam secara umum.

Menurut Zakiyuddin Baidhawy teori-teori keadilan yang ada selama ini mengandung keterbatasan dan kurang memuaskan untuk menjawab persoalan ketidakadilan secara komprehensif. Menurutnya teori kepemilikan yang ditawarkan al-Qur'an, bahwa segala sesuatu itu milik Allah, dapat menjadi alternatif. Implikasi dari pandangan itu adalah bahwa dalam kepemilikan pribadi terdapat fungsi sosial (Baidhawy, 2009:14).

Upaya untuk mewujudkan keadilan sosial tidak hanya bersifat karikatif, tetapi juga menggunakan pendekatan yang oleh Azyumardi Azra disebut sebagai "mengatasi masalah dari akarnya", yang dilakukan secara terencana, jangka panjang dan terukur dengan meningkatkan kualitas sumber daya manusia mustahiq (Azra, 2006: xiv). Hal ini tercermin dari program-program yang dijalankanya.

\section{Pertama Rumah Bersalin Gratis}

Pada awalnya Yayasan Solopeduli memiliki program santunan kesehatan. Yayasan menanggung biaya pengobatan ke rumah sakit. Berdasarkan pengalaman, layanan dari rumah sakit yang diberikan sering kurang maksimal. Utuk itu muncul gagasan mendirikan rumah sakit sendiri. Rumah sakit itu diberi nama Rumah Bersalin Gratis (RBG) berlokasi di Jalan Petir RT )1 RW 14 Jebres Surakarta yang diresmikan pada tanggal 12 Desember 2007 (Wawancara dengan Supomo, 14 Mei 2013).

Dalam perkembangannya RBG tidak hanya melayani persalinan. Dalam Company Profile Yayasan Solopeduli tahun 2012 disebutkan bahwa fasilitas yang dimiliki adalah pemeriksaan kehamilan, persalinan normal, layanan imunisasi, layanan keluarga berencana $(\mathrm{KB})$, senam ibu hamil, senam nifas, pijat bayi, pemeriksaan umum, suplemen gizi ibu dan anak, pembinaan spiritual dan layanan USG. Kontribusi rumah sakit ini terhadap gerakan civil society keperpihakannya terhadap kaum perempuan dari kalangan masyarakat tidak mampu yang sering mengalami bias gender. 
ljtihad, Jurnal Wacana Hukum Islam dan Kemanusiaan, Volume 13, No. 2, Desember 2013: 199-217

\section{Kedua Pondok Pesantren Gratis}

Pondok pesantren yang bernama Baiturrahman ini telah beroperasi sejak tahun 2008 di Jatinom Klaten. Sampai awal tahun 2013 ini masih dalam proses pembangunan, namun kegiatan ponpes Baiturrahman telah berjalan. Pada umumnya pondok pesantren hanya bisa dinikmati oleh orang berada, sementara masyarakat miskin hampir mustahil. Yayasan Solopeduli justru ingin membalik keadaan ini dengan mendirikan pondok pesantren khusus untuk anak-anak dari keluarga miskin (wawancara dengan Supomo, 14 Mei 2013).

\section{Ketiga SMK Smart Informatika Gratis}

Sekolah ini gratis bagi masyarakat tidak mampu yang diselenggarakan oleh Yayasan Solopeduli tersebut diberi nama Sekolah Menengah Kejuruan (SMK) Smart Cendikia. Penerimaan murid baru pertama dibuka pada tahun ajaran 2009/2010. Bidang ilmu yang menjadi fokusya adalah informasi dan komunikasi dengan jurusan Teknik Komputer dan Jaringan (http:// solopeduli.com $/$ main.php?module=program\&id=3\#detail, 5 Juli 2012).

Sampai saat ini gedung sekolah gratis ini masih menyewa gedung SD Negeri yang tutup karena kekurangan murid. Walaupun milik pemerintah dan digunakan untuk kepentingan sosial, namun pihak Yayasan tetap menyewa sebagaimana penyewa pada umumnya (Wawancara dengan Supomo, 14 Mei 2013). Hal ini juga menegaskan independensi lembaga ini.

\section{Keempat Ambulan Gratis}

Ambulan gratis diperuntukkan bagi masyarakat yang membutuhkannya untuk mengantar orang sakit atau pada umumnya jenazah. Sebagaimana diketahui orang yang meninggal di rumah sakit biasanya diantar dengan mobil ambulan dengan tambahan biaya tertentu. Bagi masyarakat kurang mampu biaya itu bisa memberatkan. Yayasan Solopeduli memberi layanan gratis.

\section{Kelima Program Ketrampilan}

Program ketrampilan yang disediakan Yayasan Solopeduli antara lain pelatihan setir mobil gratis, pelatihan komputer dasar, komputer desain grafis, pelatihan service HP dan pelatihan teknisi komputer. Program ini juga gratis untuk masyarakat tidak mampu. 
Keenam Program Aksi Tanggap Bencana

Program ini bersifat insidental, ketika terjadi bencana.

\section{Hambatan}

Tidak bisa dipungkiri bahwa program-program yang dilakukan oleh Yayasan Solopeduli merupakan sumbangan terhadap gerakan civil society. Secara garis besar program yang dijalankan dapat dibagi menjadi dua, yaitu pemberdayaan kaum lemah dan pembinaan kehidupan beragama. Namun jika dicermati program-program itu belum benar-benar selaras dengan civil society. Ada beberapa hambatan yang selama ini membatasi kiprah lembaga ini.

\section{Interpretasi Mustabik}

Secara umum Islam mengajarkan pembelaan terhadap kaum lemah. Banyak ayat maupun hadis yang mendukung hal itu. Ajaran filantropi, terutama zakat jelas mengarah ke sana. Persoalannya adalah bagaimana implementasi pembelaan itu mesti dilakukan. Sejauh ini program pembelaan yang dijalankan oleh Yayasan Solopeduli meskipun relatif kreatif, namun sebenarnya beranjak dari pemikiran konvensional. Pembelaan itu tidak lain adalah pemberdayaan kaum lemah secara ekonomi.

Hal-hal yang menyangkut isu kemanusiaan secara umum, seperti advokasi kebijakan yang tidak memihak kaum lemah, pelestarian lingkungan, perlindungan anak, lansia dan sebagainya tidak mendapat perhatian. Padahal hal-hal itu sangat berkaitan dengan pembelaan kepada kaum lemah, baik secara ekonomi maupun politik. Advokasi kebijakan mengenai hutang luar negeri misalnya, merupakan upaya untuk menekan beban hutang yang harus ditanggung setiap bayi yang lahir (Abidin, 2004:xi).

Memang setiap lembaga bisa memilih pola, bidang maupun isu gerakannya. Demikian juga dengan Yayasan Solopeduli. Apa yang dilakukan oleh lembaga ini bisa saja sebagai pilihan. Namun pilihan itu tentu tidak lepas dari interpretasi terhadap ajaran tentang Ziswaf, terutama interpretasi mustahiqnya. Jika delapan as \}naf dimaknai sebagaimana dalam kitabkitab fiqh karya ulama abad $8 \mathrm{M}$, tentu sulit mengikuti perkembangan di abad 21 ini. Hal ini nampaknya yang dialami oleh Yayasan Solopeduli Surakarta. 
ljtihad, Jurnal Wacana Hukum Islam dan Kemanusiaan, Volume 13, No. 2, Desember 2013: 199-217

\section{Kepentingan donatur}

Sebagai lembaga yang mengelola dana umat, Yayasan Solopeduli harus menjaga kepercayaan (trust) mereka. Pendidikan gratis misalnya, harus menghasilkan siswa-siswa yang berprestasi secara intelektual dan mental. Jika murid-murid yang dididik tidak berkualitas, maka akan muncul kesan bahwa program sekolah gratis telah gagal. Hal ini dikuatirkan akan mengurangi bahkan menghilangkan kepercayaan masyarakat.

Tuntutan akan prestasi siswa mengharuskan lembaga ini selektif dalam menjaring calon siswa yang akan masuk ke sekolah gratis. Miskin bukan satu-satunya kriteria, karena juga harus berprestasi secara akademis, baik secara moral dan bahkan perlu aktif di kegiatan keagamaan. Seleksi demikian mau tidak mau harus menyingkirkan calon-calon yang sebenarnya lebih memerlukan pendidikan. Mereka yang kurang secara ekonomi dan prestasi atau moral sebenarnya lebih memerlukan perhatian. Hal ini mengurangi kekuatan prinsip pembelaan kepada yang lemah.

\section{Jauh dari wacana civil society}

Untuk mendukung civil society tidak mesti dilakukan secara eksplisit. Substansi lebih penting. Maka sebuah lembaga, termasuk Yayasan Solopeduli Surakarta tidak harus terang-terangan berbendera civil society. Yayasan ini bahkan sama sekali tidak mengkaitkan program-programnya dengan civil society. Jauhnya wacana civil society menyebabkan Yayasan ini kurang mampu mengikuti perkembangan civil society yang relatif lebih kontekstual. Wacana civil society setidaknya dapat mendorong kepada pemahaman ajaran agama, terutama tentang Ziswaf, yang dapat mengikuti pekembangan kontemporer tanpa harus kehilangan substansi ajaran itu sendiri.

\section{Simpulan}

Zakat, infak, sedekah dan wakaf (Ziswaf) yang dikelola oleh Yayasan Solopeduli Surakarta telah memberi kontribusi terhadap gerakan civilsociety. Bentuk kontribusi itu antara lain eksistensi Yayasan Solopeduli sendiri yang ditopang oleh dana ziswaf, merupakan pilar civil society, gerakan kedermawanan, kemandirian melalui keriwaswastaan sosial, dan keadilan melalui program-program gratis. 
Di sisi lain Yayasan Solopeduli dihadapkan pada berbagai masalah yang dapat menghambat kontribusi Ziswaf terhadap gerakan civil society. Pertama interpretasi mustahiq yang masih konvensional. Akibatnya Yayasan ini tidak beranjak dari gerakan pembelaan terhadap masyarakat lemah melalui program karikatif. Kedua, Yayasan ini terikat dengan kepercayaan donatur, sehingga kadang-kadang harus mengesampingkan idealisme, seperti pemberian beasiswa yang diprioritaskan bagi yang berprestasi. Ketiga, Sejak awal Yayasan ini memang tidak mengkaitkan diri dengan gerakan civil society, meskipun secara substansi telah melakukannya. Akibatnya Yayasan ini tidak bisa mengikuti perkembangan wacana civil society kontemporer.

\section{Daftar pustaka}

Abidin, Hamid. Dompet Dhuafa Tebar Hewan Kurban (THK): Beribdah Sambil Berwiraswasta. dalam Zaim Saidi (Editor), Kewiraswastaan Sosial, Jakarta: PIRAC dan Ford Foundation, 2005.

Adi, Rianto. Metodologi Penelitian Sosial dan Hukum. Jakarta: Granit, 2004.

Ali, Muhamad. Memahami Riset Prilaku Dan Sosial. Jakarta: Pustaka Cendana Utama, 2011.

Al-Kabisi, Muhammad 'Abid. Hukum Wakaf, terj. Fathurrahman Tsani, Jakarta: Iiman, 2004

Arnaut, Muhamad M. Daur al-Waqf fï al-Mujtama' al-Islämiyah. Damaskus: Dār al- Fikr, 2000 .

Azra, Azyumardi. Sebuah Pengantar, Prospek Masyarakat Madani: Menuju Indonesia Baru. dalam Azyumardi Azra, Menuju Masyarakat Madani. Bandung: Remaja Rosda Karya, 2000.

Bamualim s, Chaidar dan Irfan Abu Bakar. Revitalisasi Filantropi Islam, Studi Kasus Lembaga Zakat dan Wakaf di Indonesia. Jakarta: Pusat bahasa dan Budaya UIN Jakarta, 2005.

Baidhawy, Zakiyuddin. “Tatanan Ekonomi Perspektif Etika Islam”. Jurnal Ijtihad. Vo. 9, No. 1 Juni 2009.

Daud Ali, Mohammad. Sistem Ekonomi Islam, Zakat, dan Wakaf. Jakarta: UI Press, 1988.

Farkhani, “Zakat (Pajak Agama) Untuk Kesejahteraan Umat.” Jurnal Ijtihad. Vol. 8, No. 2, Desember 2008.

Harmsen, Egbert. Islam, Civil Society and Social Work, Muslim Voluntary Welfare Associtions in Jordan, Between Patronage And Empowermwnt. Disertasi di Universitas Utrech Belanda, tidak diterbitkan, 2007.

Hikam, A.S. Islam, Demokrasi dan Pemberdayaan Civil Society. Jakarta: Erlangga, 1999.

Ibn Qudamah. al-Mugni. Beirut : Dār al-Kutub al-'Ilmiyyah, t.th. 
ljtihad, Jurnal Wacana Hukum Islam dan Kemanusiaan, Volume 13, No. 2, Desember 2013: 199-217

Kamil, Sukron. Pemikiran Politik Islam Tematik, Agama dan Negara, Demokrasi, Civil Society, Syari'ah dan HAM, Fundamentalisme dan Antikorupsi. Jakarta: Kencana Prenada Media Group 2013.

Madjid, Nurcholish. "Tuntutan Pengembangan Masyarakat Madani," dalam Ninok Leksono (Ed.), Indonesia Abad XXI. Jakarta: Penerbit KOMPAS, 2000.

Moore, David. "Safeguarding Civil Society In Complex Politically Environment," International Journal of No-For-Profit Law. Vol.9 No. 3, Juni 2007.

Prayogo, Imam dan Tobroni. Metodologi Penelitian Sosial-Agama. Bandung: Remaja Rosda Karya, 2003.

Prihatna, Andi Agung. "Filantropi dan Keadilan Sosial di Indonesia", dalam Bamualim dan Abubakar (Editor), Revitalisasi Filantropi Islam, Studi Kasus Lembaga Wakaf dan Zakat di Indonesia. Jakarta: Pusat Bahasa dan Budaya UIN Jakarta dan The Ford Foundation, 2005.

Pusat Bahasa Depdiknas. Kamus Besar bahasa Indonesia. Jakarta: Pusat Bahasa, 2008.

Rahardjo, Dawam, Masyarakat Madani: Agama, Kelas Menengah, dan Perubahan Sosial. Jakarta: LP3ES, 1999.

Rahman, Afzalur. Doktrin Ekonomi Islam. terj. Soeroyo dan Nastangin, Yogyakarta: Penerbit Dana Bhakti Wakaf, 1999.

Rohillah, Eva, Rully Nasrullah. Mengelola Pelayanan Kesehatan Untuk Dbuafa. Jakarta: Divisi Hubungan Masyarakat LKC, t.th.

Suyono, Yusuf dkk. Wakaf Produktif di Indonesia, Studi Atas Pengelolaan Wakaf Pondok Moderen Gontor Ponorogo 1958 - 2006, hasil penelitian kolektif DIPA IAIN Walisongo Semarang Tahun 2007, tidak diterbitkan.

Tim Penulis UII. Ekonomi Islam, Jakarta: RajaGrafindo Persada, 2008.

Tuti A. Najib dan Ridwan al-Makassary (Editor). Wakaf, Tuban dan Agenda kemanusiaan, Studi tentang Wakaf Dalam Perpektif Keadilan Sosial di Indonesia. Jakarta: CSRC UIN Syarif Hidayatullah, 2006.

Ubaidillah, Ahmad, et.all. Pendidikan Kewargaan, Demokrasi, Ham dan Masyarakat Madani, Jakarta: IAIN Jakarta Press, 2000.

\section{Internet:}

http://solopeduli.com/main.php?module=program\&id=3\#detail, diakses 5 Juli 2012 http://imz.or.id/new/news/896/potensi-zakat-nasional-217-t diakses 10 Juni 2012 


\section{Majalah:}

Majalah Hadila, Surakarta: Yayasan Solopeduli Surakarta, Edisi 49, Juli 2011, Edisi 50, Agustus 2011, Edisi 51 September 2011, Edisi 55, Januari 2012, dan Edisi 58, April 2012.

Majalah Ummi,Jakarta: PT Insan Media Pratama, No.3/XXV/Maret 20131434 H, No.4/ XXV/April 20131434 H, No.5/XXV/Mei 20131434 H, No. 6/XXV/Juni 2013 1434 H, No. 7/XXV/Juli 20131434 H.

\section{Wawancara:}

Supomo, Direktur Yayasan Solopeduli, 14 Mei 2013.

Septo Budiawan, bagian beasiswa, 20 Juni 2013.

Sri Susanti, Relawan, 25 Juni 2013. 